\title{
A TRADIÇÃO ROMÂNTICA NAS GUIRLANDAS PARANAENSES DE TADEUSZ MILAN (GRZYBCZYK)
}

\author{
Romantic Tradition in "Wianki parańskie" ["Wreaths of Parana"] by \\ Tadeusz Milan (Grzybczyk)
}

\author{
Marek STANISZ \\ Uniwersytet Rzeszowski \\ Universidade de Rzeszów \\ marekstanisz@gmail.com \\ https://orcid.org/0000-0002-1059-2893
}

RESUMO: O objeto do presente artigo é a análise do papel da tradição romântica no drama Guirlandas paranaenses (Curitiba, 1921) de Tadeusz Milan Grzybczyk (1885-1961) - publicista e poeta de expressão polonesa que chegou ao Brasil em 1904 e aqui viveu até sua morte. A obra Guirlandas paranaenses está repleta de referências à poesia romântica polonesa; é a ilustração da crença sobre a missão patriótica da poesia, um fragmento peculiar de um épico que mostra a história do "espírito" da nação polonesa; apresenta uma longa série de heróis nacionais e exibe o caráter especial do mundo representado, no qual motivos realistas coexistem com a esfera de fenômenos fantásticos e sobrenaturais. Em Guirlandas paranaenses, Milan Grzybczyk apresenta-se como um guardião da identidade polonesa, poeta-professor da história polonesa e propagador dos mitos nacionais. A ideia de independência da nação polonesa se entrelaça aqui com o postulado da liberdade individual e da irmandade inter-humana, bem como com a descrição da beleza da natureza brasileira e esperanças ligadas à nova pátria. PALAVRAS-CHAVE: Tadeusz Milan Grzybczyk; Wianki parańskie; Romantismo; Tradição romântica.

\begin{abstract}
The main purpose of the article is to analyse the role of the romantic tradition in the drama Wianki parańskie [Wreaths of Parana] (Curitiba 1921) by Tadeusz Milan Grzybczyk (1885-1961) - a poet and a newspaper columnist writing in Polish, who came to Brazil in 1904 and lived there until the end of his life. Wianki parańskie, abundant in references to Polish romantic poetry, in a sense illustrate the belief in the patriotic mission of poetry. They may also be perceived as a fragment of a heroic epic presenting the history of the "spirit" of the Polish nation, depicting a wide variety of national heroes and demonstrating the special character of the represented world in which realistic motifs coexist with the sphere of fantastic and supernatural phenomena. In the drama Wianki parańskie Milan Grzybczyk is
\end{abstract}


presented as a guardian of the Polish identity, a poet and a teacher of the Polish history and an advocate of national myths. The idea of the independence of the Polish nation intertwines here with the postulate of individual freedom and human brotherhood, as well as with descriptions of the beauty of Brazilian nature and the hopes about the new homeland. KEYWORDS: Tadeusz Milan Grzybczyk; Wianki parańskie; Polish emigration poetry; Romantic traditions of Polish poetry.

STRESZCZENIE: Przedmiotem niniejszego artykułu jest analiza roli tradycji romantycznej w utworze scenicznym Wianki parańskie (Kurytyba 1921) Tadeusza Milana Grzybczyka (1885-1961) piszącego po polsku poety i publicysty, przybyłego do Brazylii w 1904 roku i mieszkającego tu aż do śmierci. Wianki parańskie, przepełnione odwołaniami do polskiej poezji romantycznej, są ilustracją przekonania o patriotycznej misji poezji, stanowią swoisty fragment eposu przedstawiającego dzieje „ducha” narodu polskiego, prezentują długi szereg bohaterów narodowych oraz ukazują szczególny charakter świata przedstawionego, w którym motywy realistyczne współistnieją ze sferą zjawisk fantastycznych oraz nadprzyrodzonych. W utworze scenicznym Wianki parańskie Milan Grzybczyk prezentuje się jako strażnik polskiej tożsamości, poeta-nauczyciel polskiej historii i propagator rodzimych mitów narodowych. Idea niepodległości narodu polskiego przeplatała się tu $\mathrm{z}$ postulatem wolności indywidualnej oraz międzyludzkiego braterstwa, a także $\mathrm{z}$ opisami piękna brazylijskiej przyrody oraz nadziejami związanymi z nową ojczyzną. SŁOWA KLUCZOWE: Tadeusz Milan Grzybczyk; Wianki parańskie; Romantyzm; Tradycja romantyczna.

Um dos traços da cultura polonesa é um laço particular entre a emigração e a poesia. $\mathrm{O}$ fato de deixar a terra natal e a saudade que dela se sente, o peculiar estado de uma identidade dividida, o sentimento de estar entre o que é conhecido, mas foi deixado para trás e aquilo que é desconhecido, ainda que real, a consciência do hiato entre o passado e o presente, a impressão de pertencer, ao mesmo tempo, à antiga comunidade dos "seus" e à nova comunidade dos "outros", o gosto melancólico da perda misturado ao sentimento eufórico de libertação - estes pensamentos e estas emoções parecem ser especialmente úteis à expressão poética. Assim aconteceu desde os tempos do romantismo e permanece até agora: Adam Mickiewicz, Juliusz Słowacki, Cyprian Norwid, Kazimierz Wierzyński, Jan Lechoń, Józef Łobodowski, Beata Obertyńska e Czesław Miłosz - são apenas os mais afamados nomes de poetas poloneses, cujas vidas e criação ficaram para sempre ligadas à experiência da emigração. O mencionado fenômeno é, contudo, mais amplo, pois cada 
uma das diásporas polonesas, em várias partes do mundo, tem seus bardos.

Um deles é Tadeusz Milan Grzybczyk (1885-1961) - publicista e poeta de expressão polonesa que chegou ao Brasil em 1904 e aqui viveu até sua morte, em 1961, levando uma vida de início bastante ativa e, em seguida - e em parte significativa dela -, solitária e ascética nas cercanias de Curitiba, na colônia Afonso Pena. Milan Grzybczyk é um escritor que na plenitude da beleza lírica de seus versos apresentou um ardente sentimento em relação à Polônia e, ao mesmo tempo, cantou a beleza da natureza brasileira ${ }^{1}$ e, especialmente, paranaense, também entre os emigrantes poloneses assentados no local - cito palavras de Jan Sęk (1985): "sem levar em conta as visões políticas e religiosas apresentadas, tornou-se [...] o mais original poeta de origem polonesa a morar permanentemente no Brasil"'2.

O colorido curso da vida do "solitário do Paraná" é tema para um romance ${ }^{3}$ fascinante, bem como uma característica geral de sua criação literária, ainda esperando um estudioso ${ }^{4}$ que a ela se dedique. O presente artigo é apenas uma contribuição para um futuro trabalho mais amplo: nele busco mostrar o caminho da tradição romântica no drama Guirlandas Paranaenses - uma das mais importantes e maiores obras de Milan Grzybczyk. Esse, contudo, não é um tema simples, pois o romantismo funciona, na mencionada obra, como um ponto de referência fundamental: fonte de ideias patrióticas, reservatório de associações culturais, ensinamentos morais, máximas e citações.

Antes de Milan Grzybczyk tornar-se um cantor das belezas da natureza brasileira,

\begin{abstract}
${ }^{1}$ Tadeusz Milan (Grzybczyk) é o autor de um tomo poético, publicado às próprias expensas, intitulado Guirlandas Paranaenses. Peça teatral, datado de 1921. Esse tomo continha o drama do título e uma coletânea de poemas. Em período posterior, publicou poemas e artigos jornalísticos na imprensa polono-brasileira. Considerável parte de seu arquivo está em manuscritos, muitos dos quais se perderam.
\end{abstract}

${ }^{2}$ No original: ,bez względu na prezentowane poglądy polityczne i religijne uchodził [...] za najoryginalniejszego poetę polskiego pochodzenia, zamieszkałego na stałe w Brazyliił".

${ }^{3}$ Interessantes detalhes biográficos acerca da vida de Milan Grzybczyk podem ser encontrados em: SĘK, 1985 apud ARHENS, 1960, p. 25; KRAWCZYK, 1961, p. 4-9. Relato de encontro com o poeta também pode ser encontrado em OLCHA, 1971, p. 131-137. Valorosas informações sobre a etapa polonesa da biografia de Milan Grzybczyk foram compartilhadas comigo por Andrzej Dziedzic, presidente da Stowarzyszenie Miłośników Dębowca i Okolicy (Associação de Amantes de Dębowiec e cercanias), a quem, neste espaço, deixo meus mais sinceros agradecimentos.

${ }^{4}$ Além dos supramencionados artigos, que relacionam os temas memorialísticos com as características gerais da criação de Milan Grzybczyk, Agnieszka Mocyk (2005, p. 156-158) também faz referência a seus versos. Contudo, a autora não faz menção às Guirlandas Paranaenses, das quais trata o presente artigo. Jan Sęk (1986, p. 161-207) chama atenção para a escassez de trabalhos a respeito da produção literária de emigrantes poloneses no Brasil. 
ficou conhecido como um guardião da identidade polonesa, mais um poeta-professor da história polonesa e propagador dos mitos nacionais. É precisamente esse o tom das Guirlandas Paranaenses - drama em versos, de 35 páginas, escrito em 1915 (e publicado, em versão ampliada, em 1921) como resposta às necessidades artísticas dos alunos dos jovens que moravam na comunidade Afonso Pena, onde também residia Grzybczyk ${ }^{5}$. O autor, no Prólogo da edição de seus poemas, descreve as circunstâncias da produção de seu texto da seguinte maneira:

em 1915, no grupo de jovens naquele momento reunido na colônia Affonso Penna, surgiu a ideia de organizar folguedos tradicionais da Noite de São João - às margens do rio Iguassú. Com esta intenção, fui encarregado a criar uma peça para amadores que desejassem atuar no papel de faunos, rusatki etc. A trama que disto surge constitui, agora, o conteúdo do primeiro e do terceiro atos das Guirlandas Paranaenses $\left(\right.$ MILAN GRZYBCZYK, 1921a, p. 5) ${ }^{6}$

(No original: W roku 1915, w kółku młodzieży, chwilowo zebranej na kolonii Affonso Penna, powstała myśl urządzenia sobie tradycyjnej zabawy w Noc Świętojańską - nad brzegiem rzeki Iguassú. W tym celu poruczono mi obmyśleć akcję dla amatorów, pragnących wystąpić w rolach różnych faunów, rusałek itp. Powstała stąd osnowa stanowi becnie treść I i III aktu Wianków parańskich). ${ }^{7}$

Desta forma - como também podemos concluir das demais partes da introdução - a obra foi apresentada em 1915, contudo, para a edição em livro, de 1921, foram acrescentados ainda o Ato II e a cena do Juizo (MILAN GRZYBCZYK, 1921a, p. 5).

Apresentando no Prólogo sua intenção criativa, o autor chamou as Guirlandas paranaenses de "mais um fio ligando-nos à terra natal" e expressou sua esperança de que "as Guirlandas Paranaenses sirvam, no seio de nossa emigração, para despertar o sentimento de polonidade, por meio de elevados estímulos" (MILAN GRZYBCZYK, 1921a, p. 5-6).

\footnotetext{
${ }^{5}$ Nas primeiras décadas do século XX, eram bastante populares a preparação e apresentação de peças por grupos teatrais amadores no seio da emigração polonesa no Brasil.

${ }^{6}$ Todas as citações foram extraídas da edição publicada em Curitiba, 1921.

${ }^{7}$ Todas as traduções de Luiz Henrique Budant.

${ }^{8}$ No original: ,,jeszcze jedną więcej nicią łączącą nas z krajem rodzinnym”.

${ }^{9}$ No original: ,że przyczynią się one wśród naszej emigracji do rozbudzenia poczucia polskości, wypływa-jącego z wyższych pobudek".
} 
A realização destas intenções exigiu o recurso à "língua comum"10 dos mitos poloneses, frases e símbolos, que falavam aos corações e mentes, consolidados, reconhecíveis, conhecidos. Esta "língua comum" alcançou sua mais plena forma precisamente no período do romantismo, nos tempos da escravidão nacional polonesa, a qual - recordamos - ainda se mantinha em 1915.

Milan Grzybczyk dividiu sua peça em quatro atos não muito extensos. Composta de três atos e uma cena extra do Juízo, colocada, o que chama atenção, não ao final da peça, mas entre o segundo e o terceiro atos. Todas as cenas se desenvolvem às margens do rio Iguaçu na Noite de São João ${ }^{11}$, em todas - tal qual no Dziady de Mickiewicz ou na cena Preparação, que abre o Kordian de Słowacki - aparecem personagens invocadas do além. Esta convenção, de modo absolutamente claro, dialoga com uma das mais importantes ideias do romantismo: a crença sobre o inquebrantável laço a ligar o mundo visível e o sobrenatural ${ }^{12}$.

$\mathrm{O}$ ato I das Guirlandas paranaenses "remete aos tempos mitológicos da história da Polônia"13 (MILAN GRZYBCZYK, 1921a, p. 11): no palco aparecem rusałki14 e uma bruxa, figuras originárias das lendas polonesas e dos poemas românticos, e sobretudo Wajdelota ${ }^{15}$ e o Vate, que em um elevado diálogo apresentam a essência da polonidade. De acordo com suas palavras, o "espírito" nacional polonês se revela mais pleno nos ideais

\footnotetext{
${ }^{10}$ No original: ,wspólnego języka”

${ }^{11}$ As tradições folclóricas eslavas da Noite de São João, originárias ainda dos tempos précristãos, trazem à mente a tradição brasileira das Festas Juninas. Grzybczyk, certamente de modo intencional, faz referência à festa eslava - sua obra era dirigida aos emigrantes vindos da Polônia, em geral chegados ao Brasil há pouco tempo, pelos quais as Festas Juninas poderiam ser vistas como uma tradição diferente, muito pouco conhecida.
}

${ }^{12}$ Para exemplificar, Adam Mickiewicz (1997, p. 271) escreve sobre seu Dziady que sua "ideia geradora" é "a crença na influência do mundo invisível, imaterial, na esfera dos pensamentos e ações humanas" ("ideą macierzystą" jest "wiara we wpływ świata niewidzialnego, niematerialnego, na sferę ludzkich myśli i działań”)

${ }^{13}$ No original: „odnosi się do czasów bajecznych historii Polski”.

${ }^{14}$ Nas crenças populares polonesas, as rusałki eram seres fantásticos que habitavam os lagos, rios ou florestas, que com sua beleza seduziam os viajantes. Aparecem em muitas obras da literatura polonesa, principalmente no romantismo.

${ }^{15} \mathrm{Na}$ mitologia lituana pagã, Wajdelota é um espírito guia e, ao mesmo tempo, adivinho e poeta. Esta personagem foi popularizada por Adam Mickiewicz, em seu poema Konrad Wallenrod (1828). 
do amor e da entrega aos outros, pois há séculos a nação polonesa "amava - entregavase - e morria"16 (MILAN GRZYBCZYK, 1921a, p. 18), seguindo o modelo da lendária Wanda.

$\mathrm{O}$ ato II, num resumo simbólico, apresenta um "retrato espiritual da Polônia até sua queda" ${ }^{17}$ (MILAN GRZYBCZYK, 1921a, p. 11). A cena apresentada nele tem caráter visionário: eis que, diante dos olhos do Vate, surgem figuras ilustrando a história da Polônia: inicialmente Zawisza Czarny (figura que personifica a hombridade e a santidade da cavalaria polonesa, mas também dos rebelados e soldados), depois, em pose real, uma alegoria da Polônia (saudada com honra pelo Vate), a seguir o demônio Boruta (alegoria dos defeitos nacionais), e, por fim, o príncipe Józef Poniatowski (que é, aqui, símbolo da queda heroica da República das Duas Nações, sendo ele apresentado no momento de sua morte, na correnteza do rio Elstera: "a cavalo, com a espada abaixada em mãos, como são apresentados nos retratos" 18 , dizendo as palavras "A honra de minha nação, eu a entreguei nas mãos de Deus"19 (MILAN GRZYBCZYK, 1921a, p. 27) ${ }^{20}$.

Entre os atos II e III, dá-se a cena do Juízo, na qual se pesa a "balança do destino" da Polônia. Aqui, o protagonista é o Grão-Procurador "ao lado das hostes infernais"21 (MILAN GRZYBCZYK, 1921a, p. 29) - em suas falas acusatórias, ele rememora as páginas negativas da história da Polônia (marcadas pela traição, pelo egoísmo e pela corrupção), louva perversamente a ideia de progresso (ao qual muitos compatriotas serviam, esquecendo a tradição nacional e os valores comunitários), evoca toda uma plêiade de figuras (príncipes, magnatas, nobres, dignitários, banqueiros, industriais, diplomatas e religiosos, mas também comerciantes, burgueses, camponeses e até mesmo

\footnotetext{
${ }^{16}$ No original: „kochał - poświęcał się - i marł”.

${ }^{17}$ No original: „duchowy obraz Polski aż do jej upadku”.

${ }^{18}$ No original: „konno, z szablą pochyloną w dłoni, jak go przedstawiają na portretach”.

${ }^{19}$ No original: Honor mego narodu zdałem w ręce Boga!”.

${ }^{20}$ Trata-se de paráfrase das últimas palavras que teriam sido ditas por Józef Poniatowski antes de sua morte, na batalha de Lipski (1813). De acordo com os relatos históricos, teriam elas sido: “Confiou-me Deus a honra dos poloneses, apenas a Deus eu a devolvo” (No original: „Bóg mi powierzył honor Polaków, Bogu go tylko oddam.”) (MARKIEWICZ; ROMANOWSKI, 2001, p. $332)$.
}

${ }^{21}$ No original: ,W otoczeniu zgrai piekielnej”. 
judeus, ou seja, "representantes de várias classes e partidos"22 (MILAN GRZYBCZYK, 1921a, p. 11), que davam mais valor ao comportamento conciliatório e leal do que a servir a pátria. O contrapeso à massa anônima de renegados e conformistas é aqui, em primeiro lugar, o Coro, composto de quatro poetas polonesas (Adam Mickiewicz, Zygmunt Krasiński, Kornel Ujejski e Juliusz Słowacki) e, em segundo lugar, encerrando a cena, uma triunfal procissão de heróis nacionais com a divisa "nosso signo é a cruz e a espada!"23 (MILAN GRZYBCZYK, 1921a, p. 35), marchando ao passo do "hino da vitória" 24 (p. 36). Na primeira linha desta longa procissão seguem os vates, atrás deles os membros da Confederação de Bar, os soldados das Legiões de Henryk Dąbrowski, os revoltosos de 1863, os soldados do ano 1905, a I Brigada liderada (o que é curioso) por Ignacy Daszyński e, à frente de todos, "no cinzento casaco de legionário, o espírito de Chrobry - Józef Piłsudski"25 (MILAN GRZYBCZYK, 1921a, p. 37). Por conta do encerramento muito sentimental, a cena do Juízo é transformada em "apoteose da ressurreição da Polônia"26 (p. 5).

$\mathrm{O}$ ato III apresenta, a partir de uma perspectiva mais universal, o destino dos imigrantes poloneses. Eis que, durante a Noite de São João, às margens do rio Iguaçu, se iniciam as buscas por uma flor encantada que "trará felicidade ao mundo"27 (MILAN GRZYBCZYK, 1921a, p. 41) e permitirá descobrir os segredos do futuro. O mistério do futuro é, efetivamente, revelado, sendo apresentado pelo Espírito da Selva local e pelo Vate polonês. À luz de sua profecia, a chave para um futuro feliz é o labor na construção de um mundo baseado em ideais de liberdade e irmandade, na terra brasileira, na nova pátria

\footnotetext{
${ }^{22}$ No original: ,przedstawicielstwo różnych klas, partii”.

${ }^{23}$ No original: ,a hasłem naszym krzyż a miecz!”.

${ }^{24}$ No original: „hymnu zwycięstwa”.

${ }^{25}$ No original: „,w szarym legionisty płaszczu, duch Chrobrego - Józef Piłsudski”.

Józef Piłsudski (1867-1935) - um dos maiores líderes políticos poloneses. Após a consolidação da II República, em 1918, foi aclamado comandante da nação e marechal, cumprindo, até sua morte, a função de líder de fato da Polônia. Surge disto a comparação com Bolesław Chrobry, um dos mais afamados reis da história da Polônia. Ignacy Daszyński (1866-1936) - ativista político, socialista, primeiro-ministro do governo polonês em 1918, presidente do Senado da II República. Assim como Piłsudski, Daszyński atuou no sentido de formar as Legiões Polonesas em 1914, mas o comandante da famosa I Brigada dos Legionários foi Piłsudski.
}

${ }^{26}$ No original: ,apoteozę zmartwychwstania Polski”.

${ }^{27}$ No original: „co szczęście światu niesie”. 
dos emigrantes poloneses. O tom desta profecia sublinha a cena final da encenação, na qual o Espírito da Selva se transforma no jovem príncipe da lenda e suas palavras "Olhai! - este é o vosso futuro ${ }^{28}$ (MILAN GRZYBCZYK, 1921a, p. 46) são acompanhadas pela melodia da... Marselhesa.

O tom patriótico da peça é reafirmado por elementos musicais e visuais adicionais, detalhadamente descritos pelo autor nas didascálias. As cenas centrais são acompanhadas pela melodia de cantos patrióticos poloneses: Bogurodzica, Mazurek Dąbrowskiego e Chorat, esta última de autoria de Kornel Ujejski ${ }^{29}$. A atmosfera elevada é criada também por fragmentos de peças musicais fortemente ligadas à cultura polonesa: o Noturno de Frédéric Chopin (no início do ato I), bem como "os fortes acordes, a exemplo da marcha de Chopin" ${ }^{30}$ (acompanhando o monólogo do Vate, no ato II). A atmosfera específica também é criada por outras citações musicais, acentuando o caráter fantástico de algumas cenas: um acompanhamento indefinido de instrumentos que seguem o levantar-se das rusatki (no ato I), a valsa Na falach Wisty ${ }^{31}$ (acompanhando o mesmo motivo), bem como o "hino da vitória" (na cena do Juizo).

O tom musical é acompanhado por quadros vivos ${ }^{32}$ com as quais o autor enriqueceu o mundo apresentado em sua obra. E, novamente, eles apresentam personagens ou cenas simbólicas, retiradas de lendas polonesas ou da poesia romântica: o "quadro vivo de Wanda"33, circundado por personagens que fixam nela seu olhar (final do ato I- MILAN GRZYBCZYK, 1921a, p. 18), depois "o quadro vivo do motivo de Jan Słowacki 'Que os vivos não percam a esperança" ${ }^{34}$ (final do ato II - MILAN GRZYBCZYK, 1921a, p.

\footnotetext{
${ }^{28}$ No original: „Patrzcie! - to przyszłość wasza!!!”.

${ }^{29}$ Choral, de Kornel Ujejski, é um dos mais afamados poemas patrióticos do romantismo, tendo sido escrito como reação aos acontecimentos do massacre da Galícia, em 1846. Na versão cantada - com melodia de Józef Nikorowicz -, a obra se tornou excepcionalmente popular no século XIX, principalmente na região da Galícia (então ocupada pela Áustria), cumprindo lá até mesmo a função de hino nacional.
}

${ }^{30}$ No original: ,silne akordy, na przykład z marsza Chopina”.

${ }^{31}$ Trata-se de valsa composta por Adam Wroński (1850-1915), violinista, maestro e compositor polonês, a qual se tornou popular no início do séc. XX. (WROŃSKI, 1900).

32 Tableaux vivants eram uma convenção do teatro popular, entre os séculos XIX e XX. (PIOTROWSKA, 2011).

\footnotetext{
${ }^{33}$ No original: ,żywy obraz Wandy”.

${ }^{34}$ No original: ,żywy obraz z motywu J. Słowackiego Niechaj żywi nie traca nadziei”.
} 
27) ${ }^{35}$, a "apoteose da ressurreição da Polônia" "36, a encerrar a cena do Juizo ${ }^{37}$ e, finalmente, o final do ato III, no qual o "príncipe da lenda" 38 , simbolizando a liberdade, aparece, tendo por fundo musical a Marselhesa ${ }^{39}$.

Também tem origem romântica a maioria das personagens apresentadas em Guirlandas Paranaenses: tanto as figuras fantásticas (a Bruxa, rusatki, os faunos, o Demônio e seu servo Boruta, o Grão-Procurador ${ }^{40}$ ) quanto o grupo de profetas românticos (Wajdelota, o Vate, os quatro poetas românticos ${ }^{41}$ que aparecem no coro, representados como "figuras de arcanjos"42 - MILAN GRZYBCZYK, 1921a, p. 29)", e sobretudo toda a plêiade de heróis nacionais, para os quais a inventividade do autor previu até mesmo a possibilidade de extensão da peça. No Prólogo, Milan Grzybczyk declara: "considero [...] todas as Guirlandas mais como uma ideia de uma obra eternamente viva e de um epos que nunca se encerra, cujas páginas a serem preenchidas serão selecionadas pelo Espírito da nação"44 (1921a, p. 5).

\footnotetext{
${ }^{35}$ Trata-se de poema de autoria de Juliusz Słowacki, intitulado Testament mój (1840).

${ }^{36}$ No original: ,apoteoza zmartwychwstania Polski”.

${ }^{37}$ Como observa Magdalena Piotrkowska, a apoteose era um dos mais populares motivos apresentados nos quadros vivos. (PIOTRKOWSKA, 2011, p. 85-86).

${ }^{38}$ No original: „królewicza z bajki”.
}

${ }^{39}$ Tem caráter semelhante a alegoria da Polônia, apresentada no ato II como "uma virgem com uma estrela na testa, usando uma faixa em que se lê, em letras douradas, Liberum veto" (MILAN GRZYBCZYK, 1921, p. 22). No original: „dziewica z gwiazdą u czoła, przepasana czerwoną szarfą ze złotymi literami Liberum veto".

${ }^{40}$ A presença do Diabo e de Boruta (figura ao mesmo tempo cômica e diabólica) pode-se derivar da popularidade do tema fáustico na literatura romântica polonesa. (KRUKOWSKA; ŁAWSKI, 1999-2001).

${ }^{41}$ Creio que, aqui, Milan Grzybczyk refere-se ao mito oitocentista dos três vates. Na verdade, ele introduziu em seu palco quatro poetas, não apenas três, mas isto pode ser indício de que o mito dos três vates sofria alterações dinâmicas, àquela altura. Sobre este tema, consulte-se Markiewicz (1984, p. 37-71).

${ }^{42}$ No original: ,W archanielskich postaciach”.

${ }^{43}$ O motivo do "arcanjo" (ou a imagem do poeta possuidor da força de um arcanjo) aparece mais de uma vez no Konrad Wallenrod, de A. Mickiewicz, bem como nos poemas de K. Ujejski.

${ }^{44}$ No original: „Uważam [...] całe Wianki raczej za pomysł do utworu wiecznie żywego i nie kończącego się nigdy eposu, którego karty wypełniać będą wybrane Duchy narodu". 
Em quase todas as cenas das Guirlandas Paranaenses, um Vate anônimo cumpre um papel específico, dotado por Grzybczyk do poder de "ressuscitar" (invocar do alémtúmulo) outras personagens. É diante de sua face, então, que aparecem os demais personagens da peça ${ }^{45}$. Este Vate foi representado em pose arquirromântica: "lembra a figura de um mago"46 (MILAN GRZYBCZYK, 1921a, p. 13), e declama seus monólogos "de modo reflexivo", "apoiado sobre as mãos"47 (p. 19) - bem como Mickiewicz "na rocha de Judah" ${ }^{\text {" }}$, conforme apresentado no conhecido quadro de Walenty Wańkowicz ${ }^{49}$.

Nas cenas e episódios supramencionados, salta aos olhos uma intensa presença da tradição romântica. Sem dúvida, as Guirlandas Paranaenses são uma ilustração da certeza da missão patriótica da poesia, constituem um fragmento particular do epos que apresenta os feitos do "espírito" da nação polonesa, apresentam uma longa série de heróis nacionais, revelam um caráter específico do mundo apresentado, no qual os motivos realistas coexistem com a esfera dos fenômenos fantásticos e sobrenaturais.

Mas isto não é tudo. Milan Grzybczyk preencheu sua obra com criptocitações e alusões às obras poéticas românticas (particularmente Kornel Ujejski e Zygmunt Krasiński).

Os fragmentos estilizados como poesia romântica são declamados especialmente pelo coro de poetas românticos: Adam Mickiewicz, Zygmunt Krasiński, Kornel Ujejski e Juliusz Słowacki. Nos quartetos declamados por Mickiewicz, podem ser ouvidos ecos do Konrad Wallenrod (e também... dos versos de Kornel Ujejski). O Krasiński das Guirlandas paranaenses faz referência direta aos Salmos do futuro (Psalmy przyszłości), um de seus mais famosos poemas (KRASIŃSKI, 2017, p. 159-238). Nas palavras de Ujejski ressoam fragmentos de seu verso Cruz e espada! (Krzyż a miecz!) Na estrofe

\footnotetext{
${ }^{45}$ Vem à mente, aqui, a famosa Aula XVI do terceiro curso das preleções parisienses de Mickiewicz, na qual o poeta apresenta a ideia do drama nacional eslavo. Um dos pontos deste projeto foi a proposta de introdução, no palco, da figura do autor (o poeta), diante de cujos olhos deveriam aparecer as outras personagens: "a narração [...] deveria ser feita diante do público pelo poeta e ilustrada com imagens panorâmicas”. (MICKIEWICZ, 1998, p. 197).

${ }^{46}$ No original: ,przypomina postać maga”.

${ }^{47}$ No original: „w zamyśleniu”, ,wsparty na dłoni”.

${ }^{48}$ No original: ,na Judahu skale”.

${ }^{49}$ Tenho em mente o Portret Adama Mickiewicza na Judahu skale (1827-1828), pintado pelo pintor romântico Walenty Wańkowicz. Atualmente, pode-se encontrar a obra no Museu Nacional de Varsóvia.
} 
pronunciada por Słowacki pode-se, também, reconhecer ecos da Resposta aos salmos do futuro (Odpowiedź na „Psalmy przyszłości”) (SŁOWACKI, 2005, p. 373-387) (e, talvez, do Salmo do lamento (Psalm żalu) de Krasiński).

A fim de demonstrar a essência destas operações e da exatidão da estilização levada a cabo por Milan Grzybczyk, observemos um fragmento:

Quando já houverem gelado as palavras -

esperando tanto a época de dor, teremos levado o sangue teu ao jarro -

"levando o vaso de sangue e o vaso de lágrimas!" (MILAN GRZYBCZYK, 1921a, p. 30).

(No original: A gdy nam słowa zamarły już -

Czekając długo na cierpień kres,

Tośmy krew Twoją wzięli do kruż -

„Niosąc krwi dzbany i dzbany łez!”)

Os fragmentos correspondentes do poema original Cruz e espada! de Ujejski:

Já desces tu dos limiares celestiais

Nós vamos, pois, em paz ao Juízo

Levando nosso sangue derramado ao jarro;

Então tu nos perguntas: crianças, de onde? [...]

E Tu nos dizes: "sois fiel, povo!"

Ide dar o embate final ao vosso inimigo

Então poremos bandeiras em frente às cidades

Vasos do sangue nosso e vasos de lágrimas (UJEJSKI, 1900, p. 46).

(No original: $\mathrm{Z}$ niebieskich progów ty schodzisz już

To my spokojni idziem na sąd

Niosąc krew naszą zlaną do kruż;

Więc nas zapytasz: Dzieci, a skąd? [...]

A Ty nam rzeczesz: „Wiernyś ty lud!

Idź w bój ostatni wrogom na kres."

Więc miast chorągwi poniesiem wprzód

Dzbany krwi naszej i dzbany łez.)

A proximidade entre os supracitados versos é impactante. Prova disto é a criação do "nós" lírico (a representar a coletividade dos poloneses implorando ajuda a Deus), o uso dos mesmos motivos (sofrimento e sacrifício, simbolizados pelos "vasos de sangue" e pelos "vasos de lágrimas"), o ritmo idêntico na versificação de ambos os versos em 
polonês ${ }^{50}$, enfim - o alto grau de retesamento dos sentimentos patrióticos e religiosos.

De fato, nos demais fragmentos a precisão da estilização não é tão grande, mas precisamente graças a isto surge um efeito interessante: os versos ditos, nas Guirlandas paranaenses, pelos vates românticos tornam-se um enunciado só, são um equivalente da poesia romântica patriótica, com os motivos para ela característicos: sangue e sofrimento, martírio e sacrifícios postos no altar, esperança e dedicação, cruzes e espadas, o povo e o milagre. Paira sobre elas a mais romântica de todas as ideias: a crença na missão específica do poeta e na força da palavra poética, tendo o condão de transformar o "pão de cada dia" em essência angelical.

Com tal conclusão se poderia dar bom fim às presentes reflexões. Sob a intensa luz da tradição romântica, as Guirlandas Paranaenses mostram-se como expressão da imponente capacidade poética de seu autor e, concomitantemente, como testemunho legível da força do código cultural romântico, que emprestava aos emigrantes poloneses a língua para a expressão de suas emoções coletivas e reflexões identitárias. Contudo, se afastar-se, por um momento, do olhar do romantismo, pode-se enxergar as Guirlandas Paranaenses por uma perspectiva algo distinta. Eis que surgem na obra motivos que ultrapassam a imaginação oitocentista sobre a polonidade, os poloneses e o patriotismo: é a melodia da Marselhesa, o grupo de rebeldes de 1905, as figuras de Ignacy Daszyński e Józef Piłsudski e, finalmente, a potente fé na chegada de uma era de verdadeira liberdade que se poderia realizar justamente aqui, na terra brasileira. Desta maneira, em Guirlandas Paranaenses, a velha pátria (a Polônia) fica lado a lado com a nova (o Brasil), o romantismo se mistura ao socialismo, a ideia de independência nacional se plasma com o postulado da liberdade individual e da irmandade inter-humana.

A tradição romântica mostrou-se, para Grzybczyk, não apenas uma chance, mas também uma tarefa que exigia superação. Tendo em mente todos os efeitos ideológicos e artísticos das Guirlandas Paranaenses, pode-se, pois, afirmar que Milan Grzybczyk sabia não apenas evocar os mitos nacionais poloneses, imitar o estilo da poesia romântica e fazer referência às divisas românticas, mas também era igualmente capaz de processá-los, enriquecendo-os com suas próprias esperanças ligadas à nova pátria e uma ordem mais

\footnotetext{
${ }^{50}$ Guirlandas paranaenses é uma obra que, em sua totalidade, faz uso de rimas. Dominam nela, é claro, as rimas graves, mais próprias à melodia da língua polonesa, mas nas falas dos poetas surgem diversas rimas agudas, como que saídas diretamente dos poemas de Ujejski ou de Krasiński.
} 
justa no mundo.

Em 22 de setembro de 1921, nas páginas do jornal Lud, meritório órgão da comunidade polonesa no Brasil, aparece uma nota assinada por Milan Grzybczyk, informando sobre a edição, com financiamento próprio, de uma coletânea de poesias intitulada Guirlandas Paranaenses. No anúncio, o autor dá dados detalhados aos futuros compradores $^{51}$, e seu anúncio termina com a seguinte observação: "aviso que este livro serve apenas para aqueles mais inteligentes" ${ }^{\prime 52}$.

Esta admoestação particular - tão atípica -, escrita certamente em tom parcialmente humorístico, mas também parcialmente sério, entrega bem a mensagem do tomo recomendado por Grzybczyk. Apenas os leitores "mais inteligentes" conseguiriam, pois, desatar a densa tessitura de alusões literárias e evocações culturais que criam o pano de fundo poético das Guirlandas Paranaenses. E apenas "aos mais inteligentes" receptores o autor poderia endereçar a mensagem de suas poesias - ligadas às tradições polonesas e aos valores nacionais, mas também, corajosamente, dar relevo aos novos caminhos das errâncias e buscas da emigração. A língua desta nova poesia, uma poesia de dupla raiz, acabava de surgir.

Tradução: Luiz Henrique Budant

\footnotetext{
${ }^{51}$ Provavelmente, Milan Grzybczyk distribuiu as Guirlandas paranaenses parcialmente fora do mercado editorial.

${ }^{52}$ Reproduzo, aqui, trecho do anúncio: "Saiu da gráfica o primeiro livro de poesias paranaenses, intitulado Guirlandas Paranaenses. Preço do exemplar: 2\$500. Encomendas devem ser feitas junto a Konstanty Dąbrowski - Caixa Postal 313 - Curityba. Aviso que este livro serve apenas para aqueles mais inteligentes. No original: „Wyszła z druku pierwsza książka poezji parańskich zatytułowana Wianki parańskie. Cena egzemplarza 2\$500. Zamówienia przyjmuje Konstanty Dąbrowski - Caixa Postal 313 - Curityba. Uprzedzam, że książka ta nadaje się tylko dla osób inteligentniejszych. Tadeusz Milan.” (MILAN GRZYBCZYK, 1921b, p. 3).
} 


\section{REFERÊNCIAS:}

ARHENS, S. Tadeusz Grzybczyk - poeta parański. Przeglad Polski. Revista Polonêsa, São Paulo, n. 4, p. 25, jul./ago. 1960. Disponível em: $<$ http://www.pbc.uw.edu.pl/1104/1/Przeglad_Polski_1960_04.pdf $>$. Acesso em 4 nov. 2019.

CIURUŚ, E. Polacy w Brazylii. Lublin: Polonijne Centrum Kulturalno-Oświatowe Uniwersytetu Marii Curie-Skłodowskiej w Lublinie, 1977.

KACZMAREK, A. (Org.). Emigracja polska w Brazylii. 100 lat osadnictwa. Warszawa: Ludowa Spółdzielnia Wydawnicza, 1971.

KRASIŃSKI, Z. Psalmy przyszłości. In: KRASIŃSKI, Zygmunt. Dzieła zebrane: Nowe wydanie. t. 2: Poematy. Toruń: Wydawnictwo Naukowe Uniwersytetu Mikołaja Kopernika, 2017. p. 159-238.

KRAWCZYK, J. Poeta z Afosopeńskiej pustelni. Przeglad Polski. Revista Polonêsa, São Paulo, ano 2, n. 9, p. 4, maio/jun. 1961. Disponível em: $<$ http://www.pbc.uw.edu.pl/1108/1/Przeglad_Polski_1961_09.pdf $>$. Acesso em 4 nov. 2019.

KRUKOWSKA, H.; ŁAWSKI, J. (Orgs.). Postacie i Motywy Faustyczne w Literaturze Polskiej: Materiały Ogólnopolskiej Konferencji Naukowej, 23-26 out., 1997, Białystok. t. I-III. Ogólnopolska Konferencja Naukowa Białystok: Instytut Filologii Polskiej Uniwersytetu w Białymstoku, 1999-2001.

MARKIEWICZ, H. Rodowód i losy mitu trzech wieszczów. In: GŁOWIŃSKI, M.; DYBCIAK, K. (Red.) Badania nad krytyka literacka: Seria druga. Wrocław: Zakład Narodowy im. Ossolińskich, 1984. p. 37-71.

MARKIEWICZ, H.; ROMANOWSKI, A. Skrzydlate słowa: Wielki słownik cytatów polskich i obcych. Kraków: Wydawnictwo Literackie, 2007.

MICKIEWICZ, A. O poemacie Dziady in: Dzieta, $t$. $V$ : proza artystyczna i pisma krytyczne. Warszawa: Czytelnik, 1997. p. 271-273.

MICKIEWICZ, A. Wykład XVI in: Dzieła, $t$. X: Literatura słowiańska. Kurs trzeci. Warszawa: Czytelnik, 1998. p. 191-201.

MILAN GRZYBCZYK, T. Wianki parańskie: utwór sceniczny. 1. ed. Curitiba: Impressão própria, 1921a. 
MILAN GRZYBCZYK, T. Propaganda sobre a edição das Guirlandas Parananeses. Lud. 1921b, n. 39, 22 ago., p. 3. Disponível em: <http://www.pbc.uw.edu.pl/1008/1/39.pdf>. Acesso em 9 nov. 2019.

MOCYK, A. Piekto czy raj: obraz Brazylii w piśmiennictwie polskim w latach 18641939. Kraków: TAiWPN Universitas, 2005.

OLCHA, A. Brazylijskie profile. Warszawa: Ludowa Spółdzielnia Wydawnicza, 1971.

PIOTROWSKA, M. Narodowe widowiska kulturowe: uroczystości żałobne i rocznicowe w Wielkopolsce (1815-1914). Poznań: Wydawnictwo Naukowe Uniwersytetu im. Adama Mickiewicza w Poznaniu, 2011.

SĘK, J. Samotnik z Parany. Akcent, Lublin, ano VI, n. 1(19), p. 168-174, 1985. Disponível em: <http://akcentpismo.pl/pliki/archiwum/1985_1(19).pdf>. Acesso em: 4 nov. 2019.

SĘK, J. Literaci polonijni w Brazylii - zarys problematyki badawczej. In: 50 LAT TOWARZYSTWA POLSKO-BRAZYLIJSKIEGO. SEMINARIUM NAUKOWE, 2021 dez. 1984, Warszawa. Anais.... Warszawa: Zakład Krajów Pozaeuropejskich Polskiej Akademii Nauk, Towarzystwo Polsko-Brazylijskie, 1986. p. 161-207.

SŁOWACKI, J. Do autora trzech „Psalmów” (Odpowiedź na „Psalmy przyszłości” Spirydionowi Prawdzickiemu). In: BRZOZOWSKI, J.; PRZYCHODNIAK, Z. (Orgs.) Wiersze. Nowe wydanie krytyczne. Poznań: Wydawnictwo Naukowe Uniwersytetu Adama Mickiewicza, 2005. p. 373-387.

UJEJSKI, K. Poezje: nowe wydanie z wyboru autora. t. II. Lipsk: F.A. Brockhaus, 1900.

WROŃSKI, A. Na falach Wisty: walce na fortepian. Kraków: S.A. Krzyżanowski, 1900.

ZMARŁ Zmarł Tadeusz Grzybczyk, poeta parański. Przeglad Polski. Revista Polonêsa, São Paulo, ano 2, n. 8, p. 22, mar./abr. 1961. Disponível em: $<$ http://www.pbc.uw.edu.pl/1107/1/Przeglad_Polski_1961_08.pdf $>$. Acesso em 8 nov. 2019. 